\title{
THE USE OF LARGACTIL IN OBSTETRICS*
}

\section{JohN I. Davies, M.D., F.R.C P.(C), F F.A.R C.S.* *}

THE 1 deal agent and technıque for managing the problem of obstetrical analgesia has yet to be developed. In 1939 Sturrock (1) land down these six criteria for the ideal method of relieving pain in labour.

1. That is does not endanger the life of the mother or child, or in any way have an adverse effect upon them.

2. That it abolishes or effectively dimmishes pain and the memory of suffering over long periods.

3. That it does not dimmish uterine contractions and thereby delay labour or predispose to atonic post-partum haemorrhage.

4. That during the second stage it does not prevent the patient from co-operating intelligently with the doctor, so that an antiseptic and aseptic technique can be maintained.

5. That there is no necessity for operative delivery solely on account of the method used to alleviate pam.

6 That it is simple to give.

These criteria are generally accepted as reliable guides to the assessment of methods of obstetrical analgesia today. No method or agent fulfils all these requirements. The complexity of the problem is appreciated by considering the great number of drugs and diversity of techniques in use, some of which are enthusiastically advocated. It has been pointed out that routine treatment of all obstetrical patients by one method of pain relief is unsatisfactory, if not, in fact, dangerous practice (2). Furthermore, the advisability of complete analgesia and amnesia during labour has been seriously questioned, particularly by psychologists, though Cole (3) has drawn attention to the causation of foetal shock in parturition, an effect which is dimmished if the mother is adequately anaesthetized, and the average loss of weight of the baby during the first few days is definitely lessened.

A consideration of the pharmacology of the recently introduced drug Largactil suggested that it might be of value during labour and this paper reports the findings with Largactıl used alone, or with other agents, in over 100 patients delivered at the Maternity Pavilion of the Winnipeg General Hospital during 1954. This study was carried out with the invaluable co-operation of the personnel of the Obstetrical Department.

Largactıl is also known as 4560 R.P., Chloropromazine hydrochloride, and Thorazine (S.K.F). It is a Phenothiazine derivative and is related to various Thiazine dyes such as Methylene Blue and drugs such as Phenergan, Avomine, and Diparcol (Fig. 1).

\footnotetext{
"Presented at the Western Regional Meetıng, Canadian Anaesthetısts' Society, Regina, Sask., April 23, 1955.

* Department of Anaesthesia, Winnipeg General Hospital, and the Unvversity of Manitoba.
} 


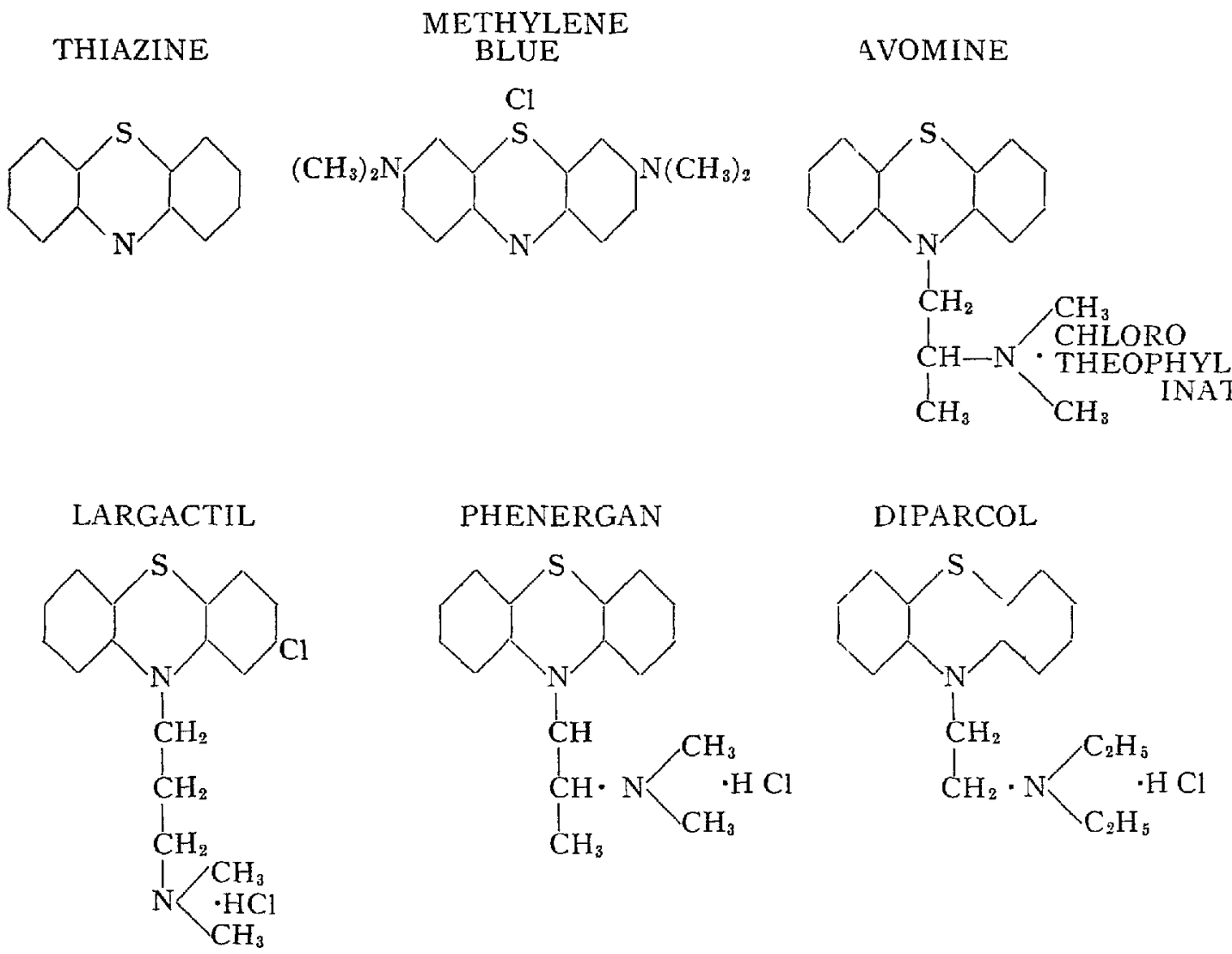

Frgune 1 Chemical structure of substances closely related to Largactil

As Largactil contains the $\mathrm{C}-\mathrm{C}-\mathrm{N}=$ linkage, it is an antihistamine according to the competitive inhibition theory (4). It has this linkage in common with many other potent drugs, and this to some extent explains its effects of either potentiatung or antagonizing pharmacologically active agents such as local anaesthetics, antihistamines, acetyl choline, and piessor amines, particularly adrenaline.

\section{Pharmacology}

The pharmacological effects of Largactil are very complicated and at present imperfectly understood, as the actions are many and diverse, and often apparently contradictory. However, the more significant and substantiated effects are briefly summarized.

\section{Effects on the Central Nervouss System}

In a review of the French work, Hopkin (5) considers the central action of Largactil most important. It is suggested that the effects are best explained by the highly developed central depressant effect on the reticular formations of the brain. The reticular formations are believed to contain centres which control vomiting, heat regulation, autonomic nervous system tone, wakefulness, muscle tone, secretions of the anterior lobe of the pituitary, and vaso-motor tone through mediation of the carotid sinus mechanism. Largactil also suppresses the 
HISTAMINE<smiles>N=Cc1c[nH]cn1</smiles>

LARGACTIL

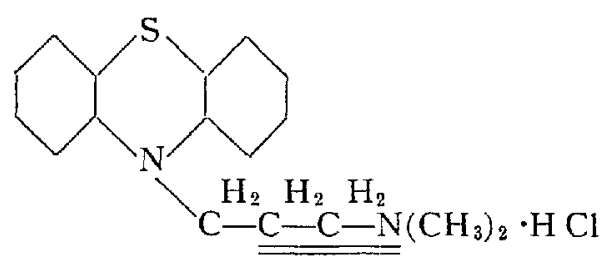

PROCAINE<smiles>CCCCCCCC(=O)C1CCNCC1</smiles>

PYRIBENZAMINE

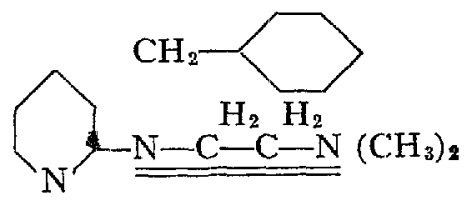

ADRENALINE<smiles>CNCC(O)C1CCCO1</smiles>

ACETYL CHOLINE

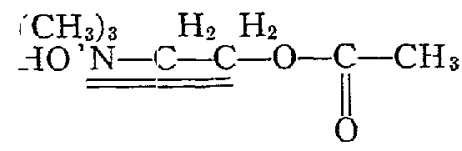

Figure 2 Chemical strụcture of some agents which Largactil may protentiate or antagonize. The -C-C-N = linkage is emphasızed.

disturbances activated through the reticular formations as the result of painful, sensory, or nocioceptive stimuli.

The central effects of peripheral sympathetic nervous stimulation are depressed, as also are the effects of endogenous or exogenous adrenaline. Cortical sensory activity is not modified and the E.E.G. shows a pattern similar to natural sleep. The well-recoggnized effects of potentiation of narcotics, general and local anaesthetics, and some muscle relaxants are probably due to these çentral depressant effects.

The peripheral effects of Largactil are also of importance and these include a powerful antagonism to adrenaline, and a less marked antagonism to acetyl choline and histamine.

The effects of Largactil on respiration have been.well described by Gilbert (6). One would not expect Largactil to be unduly depressing to the respiration of mother, or child in the dosage and combinations used in tijs series.

\section{Use of Lafigactit dURING Labour}

In 1952 Laborit (7) used Largactil and Demerol by slow intravenous infusion to suppress labour pains. Good results were claimed.

A preliminary report on the use in labour of Largactil alone, or with various combinations of drugs, has been published by Hershenson. Isaac, Romney, and 
Reid (8). In Canada, Largactil has been used during labour by many anaesthetists including Gordon (9) and Martin (10), Carroll (1..) has used Largactil in more than 200 obstetrical cases, and his results are the subject of a forthcoming paper.

\section{Material, Procedure, and Findings}

When Largactıl was used in surgical cases the great difference in the effects of oral, intiamuscular, and intravenous administration was noted. In the present series $25 \mathrm{mgm}$. of Largactıl were given intravenously durmg labour to 100 patients.

For a control series, 100 cases delivered by the same obstetricians during the same period were selected at random and compared, but toxic cases were excluded. Largactıl was given to 20 primigravidae (average age 21.6), 68

TABLE I

Sedation during First Stage

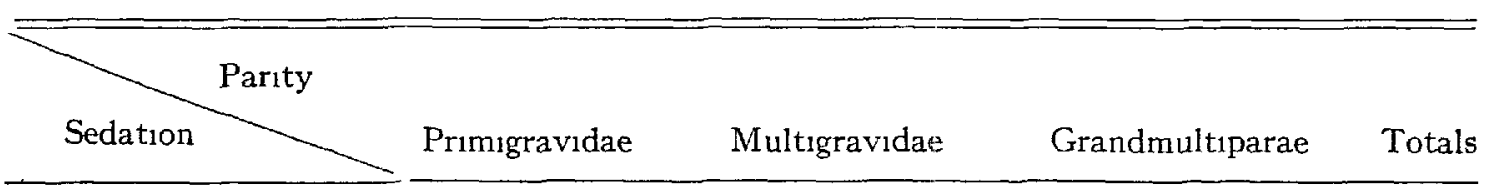

Demerol, $100 \mathrm{mgm}$

Scopolamine, gr $1 / 150$

Demerol, 100 mgm.

Demerol, $75 \mathrm{mgm}$.

Nisent1l, 40-60 mgm.

T C E , self-administered

Demerol, 25 mgm , I V

None

Demerol, $100 \mathrm{mgm}$

Scopolamine, gr. $1 / 150$

Demerol, 100 mgm

Demerol, $75 \mathrm{mgm}$

Nisentil, 40-60 mgm

T.C E , self-adminıstered

None
7

3

1

2

0

1

6

12

5

0

3

1

2
A. W1th Largact1l

16

1

24

19

2

24

6

1

8

6

0

8

4

0

4

6

0

7

11

8

25

B Without Largact1]

16

1

29

33

3

41

7

0

7

2

1

6

2

0

3

7

5 
multigravidae (average age 28.8), and 12 grandmultiparae (average age 37.5). In the control series there were 23 primigravidae (average age 22.1), 67 multigravidae (average age 28.8), and 10 grandmultiparae average age 39.5).

\section{MANAgEMENT}

During the course of labour, analgesics were administered if considered necessary by the attending staff.

As labour progressed Largactil $25 \mathrm{mgm}$., diluted in $10 \mathrm{cc}$. of normal saline, was given intravenously when considered indicated.

Apart from patients experiencing early distress in labour, Largactil was given with best effect in primigravidae "just before full cervical dilation and in multigravidae when the cervix was about half dilated.

Following Largactil, the patients usually became dramatically relaxed within two minutes, sleeping peacefully between pains but easily roused. They would awaken during uterine contractions or rectal examination. They would co-operate well. Where apprehensıon was present it was invariably relieved when Largactil was given.

The psychic sedative effect was most marked in eight patients, including four primigravidae, who became almost unmanageable during the first stage of labour. One was a diagnosed psychotic patient and another known to be suffernng from hysteria. After Largactil, all eight patients became more calm, peaceful, and co-operative.

It will be seen from Tables II and III that Largactil did not increase the need for operative delivery, as spontaneous delivery occurred 64 times when Largactil had been used, compared with 57 spontaneous deliveries in the control series.

It was often observed that patients who had received Largactil had an unusually relaxed perineum. As a result the incidence of episiotomy was decreased, and it is also seen from Table III that the number of intact perinei was 55 compared with 36 in the control series.

The episıtomies or perneal tears were repaired under local infiltration with 2 per cent Procaine without additional anaesthesia when Largactıl had been used, while in the control series general anaesthesia was necessary in addition to the local infiltration in nine cases. In three additional cases in which local infiltration was inadequate for epısıtomy repair, Largactl was given instead of general anaesthesia and was satisfactory.

Supplementary anaesthesia was not considered necessary for 32 patients who had received Largactul. Of these, 18 patients had received either Demerol or Demerol and Scopolamine, 4 had been given Demerol $25 \mathrm{mgm}$. intravenously; thus 10 patients had received Largactil only during the course of their labour.

The use of Largactil greatly reduces the need for supplementary anaesthesia and particularly deep general anaesthesia for operative deliveries. Nitrous Oxide with 30 to 40 per cent Oxygen was adequate for most procedures. Emergence from anaesthesia was not delayed; all patients were returned to the ward as usual and special nursing care was not considered necessary. Following Largactil, administration of general anaesthesia was unusually smooth and stridor when traction was applied to obstetrical forceps was noted in only three patients, in 
TABLE II

Average tımes from adminıstering the sedative drug to giving Largactıl and average times from giving Largactıl to full cervical dilatation and to the time to delivery

\begin{tabular}{|c|c|c|c|c|c|c|}
\hline \multirow[t]{2}{*}{ Average Times } & \multicolumn{2}{|c|}{ Prımıgravidae } & \multicolumn{2}{|c|}{ Multıgravidae } & \multicolumn{2}{|c|}{ Grandmultiparaf } \\
\hline & $\mathrm{Hr}$. & $M_{1 n}$ & $\mathrm{Hr}$. & Min & $\mathrm{Hr}$ & Min \\
\hline Sedation to Largactil & 2 & 35 & 1 & 35 & 1 & 33 \\
\hline $\begin{array}{l}\text { Largactil to full cervical } \\
\text { dilatation }\end{array}$ & & 364 & & 312 & & 462 \\
\hline Largactil to delivery & 1 & 14 & & 442 & & 505 \\
\hline
\end{tabular}

TABLE III

Course of Labour in Both Serjes

\begin{tabular}{|c|c|c|c|c|c|c|c|c|c|}
\hline \multirow{5}{*}{ 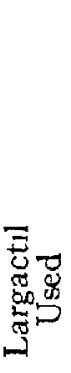 } & Delivery & \multirow{2}{*}{ Spontaneous } & \multicolumn{4}{|c|}{ Operative delivery } & \multicolumn{3}{|c|}{ Perineum } \\
\hline & Parity & & $\begin{array}{l}\text { Outlet } \\
\text { forceps }\end{array}$ & $\begin{array}{c}\text { Rotation } \\
\text { and } \\
\text { forceps }\end{array}$ & $\begin{array}{l}\text { Breech } \\
\text { with } \\
\text { Prper's }\end{array}$ & Face & Intact & $\begin{array}{l}\text { Epis. } \\
\text { 1otomv }\end{array}$ & Rear \\
\hline & Primıgravidae & 7 & $12^{*}$ & 1 & $1^{*}$ & 0 & 5 & 13 & 2 \\
\hline & Multigravidae & 46 & $12^{*}$ & 7 & $4^{\text {ta }}$ & 0 & 38 & 21 & 9 \\
\hline & Grandmultigravidae & $11^{*}$ & 1 & 0 & $1^{*}$ & 0 & 12 & 0 & 0 \\
\hline 苛 & Primigravidae & 6 & 12 & 5 & 0 & 0 & 5 & 17 & 1 \\
\hline 胥苋 & Multigravidae & 44 & 12 & 8 & 2 & 1 & 23 & 37 & 7 \\
\hline$z^{\circ}$ & Grandmultigravidae & 7 & 1 & 2 & 0 & 0 & 8 & 2 & 0 \\
\hline
\end{tabular}

*Including twin deliveries

TABLE IV

Anaesthetic agents used when supplementary anaesthesia was necessary and also the agents used in the control group

\begin{tabular}{lrc}
\hline Supplementary anaesthesia & $\begin{array}{c}\text { Largact } 11 \\
\text { used }\end{array}$ & $\begin{array}{c}\text { Largactil } \\
\text { not used }\end{array}$ \\
\hline $\mathrm{N}_{2} \mathrm{O}-\mathrm{O}_{2}-\mathrm{Cyclo}$ & 15 & 56 \\
$\mathrm{~N}_{2} \mathrm{O}-\mathrm{O}_{2}-\mathrm{T} \mathrm{C} \mathrm{E}$ & 0 & 21 \\
$\mathrm{~N}_{2} \mathrm{O}-\mathrm{O}_{2}$ & 52 & 10 \\
Spinal & 1 & 0 \\
TC E , self-administered & 0 & 5 \\
None & 32 & 8 \\
\hline
\end{tabular}


spite of the light level of anaesthesia. Perhaps Largactil depresses the sacro-vagal "stretch" reflexes.

\section{Assessment of SEDatton}

The objective evaluation of pain relief in labour is difficult as criteria are usually a matter of individual opinion. However, in the first stage $\mathrm{c}$ nd during the second stage up to imminent delivery, relief of suffering was consic ered excellent or good in 87 patients. As Largactil is not a true analgesic it is to be expected that of the 13 patients in whom relief was only moderate, 5 had received less analgesics than usual, while 8 had received only Largactil. Towards the end of the series, if no analgesic had been given and labour was progressing well, Demerol $25 \mathrm{mgm}$. was given intravenously mixed with the Largactil. Satisfactory sedation was obtained in all such cases.

Subjective evaluation is equally unreliable, but on ques ioning on the second or third day after delivery, the patients gave the following estimate of pain relief during labour: excellent or good, 83, poor, 4; non-committal, 8; 5 were unreliable because of language difficulties. When this delivery was compared with previous or later deliveries, most patents stated that with Largactil they had an easier time.

Amnesia was unusual except in those patients who had received Scopolamine. It must be remembered when considering these results that supplementary anaesthesia was used in 68 cases.

\section{DURATION OF LABOUR}

The effect of Largactl on the duration of labour is difficult to assess, as it is notoriously difficult to predict the course of even apparently normal labou:. The opinion of highly experienced Labour Floor personnel was that labour was definitely speeded up in 6 of the 8 unmanageable patients, apparently speeded up in 6 multıgravıdae, and in one grandmultipara.

However, labour seemed to be slowed down in 4 multigravidae and in 5 grandmultparae. All these patients were having irregular pains and poorly sustamed uterine contractions. It would appear unwise to give Largactil to patients who are in no distress, or those in whom uterine contractions are infrequent or poorly sustamed. This applies particularly to grandmultiparae who, in any case, have little need for the benefits of Largactil. Largactil was given in one case of primary uterine inertia with no apparent effect on the course of labour.

It will be seen from Table $\mathrm{V}$ that the elapsed times for the various stages of labour are comparable except in the case of grandmultiparae, and this tends to support the clinical impressions regarding the effect of Largactil on uterine contractions in grandmultiparae.

\section{Effect of Lafigactil on the ThmRd Stage of Labour}

Routinely $1 / 2$ cc. of Pitocin was given after the head was delivered and 0.5 mgm. Ergometrine when the placenta and membranes were delivered intact.

The placenta was expelled in 17 cases and expressed in 83 cases receiving Largactil. No manual removal of the placenta was-performed, but one patient 
TABLE $\mathrm{V}$

Duration of Three Stages of Labour in Both Series

\begin{tabular}{lccccccc}
\hline & \multicolumn{3}{c}{ Largactıl used } & & \multicolumn{3}{c}{ Control series } \\
\cline { 2 - 4 } \cline { 6 - 7 } \multicolumn{1}{c}{ Parity } & 1st stage & 2nd stage & 3rd stage & & 1st stage & 2nd stage & 3rd stage \\
\hline Primigravidae & Hr Min & Min & Min & & Hr Min & Min & Min \\
Multigravidae & $11-58$ & -532 & -107 & & $10-16$ & -531 & -82 \\
Grandmultiparae & $6-34$ & -168 & -69 & & $8-30$ & -206 & -60 \\
& $8-06$ & -412 & -94 & & $2-10$ & -191 & -21 \\
& & & & & & &
\end{tabular}

was seen 16 days post partum with uterine bleeding and a small placental remnant was removed under general anaesthesia.

In the control senes the placenta was expelled in 19 cases, expressed in 80 cases, and manual removal was necessary in one case.

In the cases receiving Largactil, there was one post-partum haemorrhage estimated at $750 \mathrm{cc}$. This occurred in a grandmultipara. In the control series there were two haemorrhages estımated at greater than $600 \mathrm{cc}$.

Haemoglobin estımations were made during antenatal care in 83 patients and averaged 75.2 per cent Post-partum haemoglobin estımated on the 4th to 5 th day in 96 cases showed an average reading of 87.7 per cent. In the control series the average haemoglobin values were 74.6 per cent antenatal and 868 per cent post partum.

The duration of the third stage was not significantly different in the two serıes.

\section{EFFECT ON THE BABY}

No change in foetal heart sounds was detected after Largactil. The number of babies born was 103 including three sets of twins.

Seven babies weighed less than $2500 \mathrm{gm}$. ( $5 \mathrm{lbs} .5 \mathrm{oz}$ ) and were considered premature. There was one still birth due to hydrops foetalıs (dragnosed intrauterme) and two neonatal deaths. One was a case of impacted shoulders in a baby weighing $10 \mathrm{lbs} .1 \mathrm{oz}$. and was considered a preventable obstetrical death. The other was in a premature baby weighing $4 \mathrm{lbs}$. $9 \mathrm{oz}$. The Apgar rating at birth was 8 , but the baby became cyanosed after 6 hours and died on the 4th day. An autopsy showed respiratory hyalne membrane dissease. Apart from these, the babies all breathed within one munute and were unusually pink. This may have been the result of placental transmission of the Largactıl causing peripheral vasodilatation of the baby.

The average Apgar rating was 8.9 and all but two babies had an Apgar rating greater than 6 after one minute. One, a premature baby of $4 \mathrm{lb} .12 \mathrm{oz}$., recovered without active resuscitation to an Apgar 8 rating in 3 minutes. The other, the first of undiagnosed twins, had an Apgar rating of 5 whle the second had an Apgar 9 rating. Thus placental transmission of Largactil was not the cause of the depression of the first twin. 
In the control group, which included 6 premature babies, there were 2 stillborn babies and 3 neo-natal deaths. The average Apgar rating was 8.4 and six babies had an Apgar rating of less than 6 after one minute, four of these requiring resuscitation.

\section{General EFFects}

There was no maternal mortality in either series. The cardiovascular system seemed to be spared ill effect. Following Largactil peripheral vasodilatation was usually observed and was particularly noticeable in the hand and arm veins. In spite of this no change in blood pressure greater than 10 per cent occurred except in 6 excitable patients, when the blood pressure dropped to within normal limits. Pulse rate increased more than 10 per cent in 23 patsents, and this effect was more pronounced if the Largactll had been given quickly.

Nausea and vomiting are often a problem durng labour, particularly when general anaesthesia is used. The dangers of aspiration of vomitus during obstetrical anaesthesia are fully appreciated by most obstetricians and anaesthetssts, yet reports of such disasters are all too common. The classical paper of Mendelson (12) in 1946 describes the dangers in detail as does a recent paper by Parker (13). Glllat (14) found inhalation of vomitus the cause of death in 3 out of 55 maternal deaths and stated emphatically that these were deaths "which should not have occurred." Klein (15) in a report of 413 maternal deaths attributed 22 to anaesthesia, and of these 7 were due to aspiration asphyxia. The conclusion was that maternal mortality from anaesthesia had risen in that series from 2 to 9 per cent in a six-year period. As 11 of the 22 deaths were attributed to spinal anaesthesia, this method would not seem to be the answer to this particular problem.

The anti-emetic effects of Largactll are well known and have been used to great benefit in vomitng in many apparently dissimilar conditions (16-18), and in the reduction of post-anaesthetic vomiting by Gordon (19) and later by Caphn and Code Smith (20).

In the senes in which Largactil was used, 7 patients suffered from nausea and vomiting during the first stage of labour. In all cases nausea and vomiting stopped soon after Largactil was given and the symptoms did not return. Following supplemental general anaesthesia two patients complained of nausea and one vomited a small amount. No patients complained of nausea or vomiting after leaving the case roora.

In the control series, 9 patients vomited during the first stage of labour. Following general anaesthesia, 17 patients complamed of nausea and 13 vomited. Later in the ward 10 patients complained of nausea and 6 vomited.

The greatly reduced incidence of nausea and vomiting in the Largactil series is attributed not only to the anti-emetic action of Largactil but also to the very much smaller amounts of general anaesthetic agents required, particularly cyclopropane.

No clinical evidence of liver or kidney damage was seen, and there was no increased incidence of post-partum catheterization. 


\section{Post-Partum CondtTion}

The patients who had received Largactil were peaceful, relaxed, and drowsy for about six to ten hours. Complaints of afterpains or from episiotomy wounds were few. Although the patients were sleepy, they were co-operative and voluntary fluid intake was not reduced. Patients of both series received Medinal gr. V or Frosst 292 at the discretion of the ward supervisor. Those patients who had received Largactıl were given an average of 1.5 medications in the first twenty-four hours post partum, while the control patients received an average of 3.7 medications.

\section{In Mild Toxaemia}

Other Obstetrical Uses

During labour, Largactıl was given to an additıonal 8 patıents suffering from mild toxaemia. Three were prımıgravidae, 4 multigravidae, and 1 a grand multipara. Other sedation was with Demerol and Scopolamine or barbiturates as determined by the obstetrician. The combined sedative effect was excellent. Labour was rapid in all cases resulting in 4 spontaneous and 4 outlet forceps deliveries. Blood pressure was reduced in 7 cases to within normal limits and no complications or ill effects were observed.

\section{Eclampsia}

Largactil would seem to be of value in treating eclampsia and pre-eclampsia by potentiating the effect of the usual sedative drugs However, great caution should be used in combining Largactil with narcotic drugs in the presence of liver damage. Largactl has been used in one such case at the Maternity Pavilion and the results are the basis of a separate report.

\section{Hyperemesis Gravidarum}

The value of antihistamines in hyperemesis gravidarum was described by Dougray (21) and the use of Largactil by Rouchy (22). Largactil has been used in close co-operation with the obstetrician in 11 cases of hyperemesis gravidarum when other methods of treatment had met with little success. Largactil $50 \mathrm{mgm}$. was added to $1,000 \mathrm{cc}$. of 5 per cent Dextrose and the mixture slowly given intravenously. After 300 to $500 \mathrm{cc}$ of the mixture had been given, nausea was improved in all cases and when $750 \mathrm{cc}$ had been given the patients were exhorted to take bland fluid and perhaps toast by mouth Largactıl $25 \mathrm{mgm}$. was given orally and the intravenous infusion continued until 1,000 $\mathrm{cc}$ had been given Oral Largactil, $25 \mathrm{mgm}$ q.d.s, was continued and the patient kept on a dally maintenance dose of 25 to $50 \mathrm{mgm}$. for at least ten days. This was successful, at least temporarily in all cases. On this dosage most patients complained of an aggravation of the feeling of lassitude which is a frequent accompaniment of early pregnancy. This was effectively relieved by concurrent administration of Dexedrine $5 \mathrm{mgm}$. in the morning.

\section{Caesarian Sections}

Largactil was used in 5 cases of Caesarean section. Four were "repeat sections" and one was a case of placenta praevia. 
Largactl $25 \mathrm{mgm}$. was given intravenously 30 to 45 minutes before the time of operation. Induction and maintenance was with Nitrous, Oxide and Oxygen. A continuous succinyl-choline drip was used to provide adequate relaxation when required. Operatıve conditions were excellent and all babies breathed spontaneously. No ill effects on mother or child were seen.

The postoperative condition of the mothers was good and treatment in a postoperative recovery room was not considered necessary.

\section{Summary alND Conclusions}

Largactil $25 \mathrm{mgm}$. was given intravenously to 100 patients during labour and the results compared with the course of labour in 100 similar cases.

Following the adminustration of Largactl excellent psychic sedation was usually observed. The patients became relaxed immediately, slept between pains, but could be easily roused. Apprehension was relieved.

The best results were obtained when an analgesic was also used during the first stage of labour. Largactil was used to best advantage when given to primigravidae just before full cervical dılatation and to multigravidae when the cervix was about half dilated. If no analgesic had been given the simultaneous administration of Demerol $25 \mathrm{mgm}$. intravenously with the Largactil produced better sedation.

For the actual delivery, if general anaesthesia was necessary, the amounts necessary were greatly reduced, Nitrous Oxide-Oxygen being sufficient for most operative deliveries.

Post-partum sedation was required less often.

Vomiting during labour was relieved by Largactil and the incidence of nausea and vomiting after general anaesthesia and delivery was significantly decreased.

No 1 ll effects on mother or child were observed.

It would appear that Largactll would be useful in premature deliveries as it does not have any apparent narcotizing eflect on the baby, and by its use the amounts of analgesics and anaesthetics can be greatly reduced.

Largactil sometımes appears to have a tendency to slow up labour, particularly in grand multiparae and those patients with poor uterme contractions.

In Caesarean section, Largactil combined with light anaesthesia and a muscle relaxant appears to be effective and safe.

It is suggested that Largactil deserves further investigation of its uses in obstetrics.

\section{ACKNOWLEDGMENTS}

The invaluable co-operation and guidance of Dr. Elinor Black, Chief of the Department of Obstetrics, is greatly appreciated. Acknowledgments are made to the resident and intern staff and particularly to the Labour Floor and case room personnel for their assistance and suggestions.

The help of Dr. Donalda Huggins and members of the Anaesthetic staff is acknowledged.

The Largactil used in this study was generously supplied by Poulenc Limited. 


\section{RÉSUMÉ}

Cent patients en travail reçûrent $25 \mathrm{mgm}$. de Largactil en injection intra veineuse et les résultats obtenus furent comparés à ceux de 100 autres patients présentant la même condition.

Habituellement l'administration du Largactil fut suıvie d'une excellente sédation psychique. Les patientes devinrent immédiatement calmes, dormièrent entre les douleurs mais purent être facilement éveillées. L'appréhension disparût. Les meilleurs résultats furent obtenus quand on utilisa aussı un analgésique durant la période initiale du travall. Le Largactıl fut employé avec le maximum d'effet quand on l'injecta aux primıpares avant dilatation complète du col et chez les multipares, quand le col était a moitıé dılaté. Quand aucun analgésiquie n'avait été donné, l'injection simultanée en intra verneuse, de $25 \mathrm{mgm}$. de Demerol et du Largactil produisit une meilleure sédation.

Quand il fut nécessaure d'employer l'anesthésie générale au moment de la délivrance, la quantité en fut moindre et le plus souvent le mélange protoxyde d'azote-oxygene fut suffisant.

On n'eut moins besoin de sédation après le travail.

Le Largactil fit disparaître les vomissements durant le travall et diminua grandement lincidence des nausées et vomissiments après l'anesthésie générale et la délivrance.

Aucun effet noscif sur la mère ou l'enfant fut observé.

Il semble que le Largactil pourrait être employé avec succès dans les accouchements prématurés. Il n'a aucun effet narcotique sur le bébé et son emploie diminue de beaucoup la dose des analgésiques et anesthésiques.

Par fois le Largactil semble avoir une tendance a ralentır le travall, particulièrement chez les grandes multipares ou chez les patients a faibles contractions utérines.

Dans les Césaréennes, le Largactıl employé avec une anesthésie peu profonde et une curarisant semble effectif et sur.

L'auteur suggère qu'on étudie davantage les possibilités du Largactil en Obstétrique.

\section{REFERENCES}

1 Sturnock, J Relief of Pain in Labour J Obst \& Gynaec 46426 (1939).

2 Editorial Obstetrical Anaesthesia Canad. Anaesth Soc J 157 (1954).

3 Cole, W C C Obstetrical Influences on Werght Curve of Newborn Surg, Gynec \& Obst $68 \quad 179$ (1939)

4. MARTiN, G J Biological Antagonısm 1st ed, Garden City, N Y Blakiston (1951), Pp 47-55.

5. Hopkan, D A. B. The Action of Chlorpromazine Review of French Work Lancet 1. 605 (1955).

6. Dobkin, A. B., Girbert, R G. B \& Lamoureux, L l?hysiological Effects of Chlorpromazine. Anaesthesia 9. 157 (1954).

7. LABORIT, H L'anesthésiologie obstétricale Maroc méd 330 (1952)

8 Hershenson, B. B, Isaac, S I, Romney, S. L \& REm, D E. New Sedative (Antipsychomotor) Drug Useful in La jour New England J. Med 6216 (1954).

9 Gohdon, R. A Address to Winnipeg Anaesthetists' Society, April 20 (1955).

10 Maftin, E M Personal communication

11. Carroll, J. J Personal communication. 
12. Mendelson, C L Obstetrical Analgesia and Anesthesia. Am. J Obst \& Gynec. 52: 191 (1946).

13. PARKEn, R. B. Risk from the Aspiration of Vomit during Obstetrical Anaesthesia Brit. M J. 1165 (1946).

14. Gilliat, Sir W. Trans. 12th Brit Congr. Obst. Gynaec. 269 (1949).

15. Kleti, M. D., Clahr, J, TAmis, A B \& Soklow, M L. Maternal Deaths Caused by Anesthesia in the Borough of the Bronx from 1940 to 1951. New York J. Med 53: 2861 (1953).

16 Moyer, J H, Kent, B, Knight, R. W., Morris, G, Dizon, M., Rogers, S \& Spurr, C. Clinical Studies of an Anti-Emetic Agent, Chlorpromazıne. Am J Med. 2 228 (1954).

17. Friend, D G \& Cummings, J. F Use of Chlorpromazine in the Treatment of Nausea and Vomiting of Uremia New England J Med 23997 (1954).

18 Marks, J H Use of Chlorpromazine in Radiation Sickness and Nausea from Other Causes New England J. Med. 23999 (1954)

19 Gordon, R. A, Vandewater, S. L, Slearim, G. E \& Caplin, D. A Study of the Value of Dimenhydrinate and Promethazine Hydrochlonde in the Control of Post-Anaesthetic Vomitung. Canad Anaesth. Soc. J. 1 95 (1954).

20 Caplin, D \& SMrth, C. A Comparison of the Ant1-Emetic Effects of Dimenhydrunate, Promethazıne Hydrochlonde and Chlorpormazine following Anaesthesia. Canad. Anaesth Soc. J 2191 (1955).

21 Dougray, $T$ Anthistamines in the Treatment of Nausea and Vomitng of Pregnancy. Brit M J 21081 (1949).

22 Rouchy, $R$ Les vomissements incoercibles de la gestation et la cure de sommerl: L'utılisation du 4560 R.P. Presse méd. 62 (1952). 